DOI: $10.31249 / \mathrm{rsm} / 2021.03 .02$

\title{
У.Н. Хазыр
}

\section{ЗАПАА КАК ОБРАЗЕЦ? СРАВНИТЕАЬНЫЙ АНААИЗ ОПЫТА МОАЕРНИЗАЦИИ РОССИЙСКОЙ И ОСМАНСКОЙ ИМПЕРИЙ В ТУРЕЦКОЙ АИТЕРАТУРЕ}

Аннотация. В турецкой литературе уделяется особое внимание сравнению османской (турецккой) и российской вестернизации /модернизации. Это не случайно, поскольку обе континентальные и многоэтнические империи, соседствовавиие и конкурировавшие между собой, рассматривали Запад как образец модернизации и имели некоторые общие черты с точки зрения прочесса вестернизации. На протяжении более чем двух столетий и Туричи, и Россия несколько раз попытались стать полноправными членами «клуба» европейских стран, частью западной политической системы и цүивилизации. В статье представлен анализ турецких исследований, отражаюших «незападный» взгляд на модернизацию / вестернизацию. Автор приводит публикации и рассматривает позищии наиболее выдающихся турецчких ученых в области исследования турецкой вестернизации и модернизаџии. Источниковую базу представляют статьи, опубликованные с 1960-х годов и до сегодняшнего дня. Автор представляет обзор интерпретаций Запада и вестернизации, а также знакомит с оценками российской модернизации, принадлежащим турецким ученым. Таким образом, изучение турецкой литературы позволяет российской аудитории лучше понять современные проблемы в отношениях Турции и России с Западом, а также способствует более глубокому анализу турецкк-российских отношений потому, что Запад и вестернизаџия заметным образом отразились на двусторонних отношениях указанных стран. Автор выделяет определенные пробель в сравнительных исследованиях, показывает, что турецкие ученые считают российскую вестернизацию более успешной по сравнению с османской, а также выделяют важные различия двух модернизациий / вестернизаций.

Ключевые слова: вестернизаџия; модернизаџия; Запад; Россия; Османская империя; Турцчия.

\footnotetext{
Хазыр Умит Назми - аспирант Школы политических наук

Национального исследовательского университета

«Высшая Школа Экономики». Россия, Москва.

E-mail: umitnh@gmail.com

Web of Science Researcher ID: Y-8052-2018
} 


\title{
Hazır Ü.N. The West as a Model? The Comparative Analysis of the Modernisation Experiences of the Russian and Ottoman Empires in Turkish Literature
}

Abstract. In Turkish literature, one of the subjects studied mainly by Turkish scholars has been the comparison of Ottoman (Turkish) and Russian westernisations / modernisations, since these two rival, neighbouring, continental and multi-ethnic empires considered the West as a model for their modernisations and had some parallelisms in terms of westernisation. On several occasions, both the Turks and Russians attempted to become full-fledged member of the 'club' of great European countries, Western political system and civilisation for more than two centuries. As a review article, this work offers Russian audiences Turkish (non-Western) perspectives on comparing the Ottoman and Russian westernisations through the analysis of Turkish literature. This article appealed to the publications and opinions of the most outstanding Turkish academics bearing deep knowledge on Turkish westernisation and modernisation. The time of the publications ranges from the $1960 \mathrm{~s}$ to today. By way of this article, Russian audiences would be able to learn how Russia and Russian westernisation evaluated by Turkish academics; and what Turkish academics understand from the West and westernisation. Furthermore, Turkish literature enables Russian audiences to better understand contemporary issues in the relations of Turkey and Russia with the West as well as to analyse Turkish-Russo relations more properly since the fact of the West and westernisation affected the bilateral relations of these two countries. Besides, this article demonstrates to Russian audiences the gap in Turkish literature regarding the comparison of Turkish and Russian westernisations. This article argues that Turkish scholars consider Russian westernisation more successful than Ottoman westernisation and underline huge differences alongside similarities within their modernisations / westernisations.

Keywords: Westernisation; Modernisation; the West; Russia; the Ottoman Empire; Turkey.

\author{
Hazır Ümit Nazmi - Ph.D. Student at National Research \\ University Higher School of Economics. Russia, Moscow. \\ E-mail: umitnh@gmail.com \\ Web of Science Researcher ID: Y-8052-2018
}

\section{Введение}

Модернизация (или вестернизация, как ее чаще называют в Турции) была серьезной проблемой и для Османской, и для Российской империй, начиная с XVIII в. Она породила множество споров и дискуссий в обществе и научной среде. Есть немало работ, посвященных сравнению турецко-османской вестернизации с японской и особенно - с российской [Alatlı 2005; Belge 2004; Belge 2016; Acar 2008; Gündoğdu 2006; Esenbel 2019]. Проблемы русской вестернизации привлекали внимание по причине очевидного сходства. Во-первых, будучи соперниками, соседями, континентальными и многоэтническими империями, Османская империя и Россия встали на путь модернизации позже, 
чем их западноевропейские соседи. Во-вторых, лидеры обеих стран рассматривали Запад как образец проведения модернизации. В-третьих, в самом процессе модернизаций обеих империй имели место общие черты. Наконец, фактор Запада и вестернизация повлияли на политические идеи и дискуссии по вопросам идентичности и в Турции, и в России.

Предлагаемый в настоящей статье обзор турецкой литературы, посвященной сравнительному анализу двух модернизаций, может быть интересен для российского читателя, поскольку он знакомит с незападными подходами к вестернизации. Кроме того, он поможет лучше понять современные проблемы, возникающие в отношениях Турции и России с Западом, а также в их двусторонних отношениях. В англоязычной литературе сравнивались лишь некоторые аспекты турецкой и российской модернизации [Brisku 2017; Agoston 2011]. Модернизация Османской и Российской империй сравнивалась Адрианом Бриску с точки зрения политических реформ и Габором Агостоном с точки зрения военных реформ [Brisku 2017; Agoston 2011]. Однако некоторые аспекты вестернизации и модернизации обеих стран, такие как роль религии, не нашли отражения в англоязычной литературе. В этом смысле турецкие исследования могут послужить полезным дополнением.

Споры о модернизации и вестернизации повлияли на интеллектуальную и политическую историю Турции и России. Отношения и противоречия между Россией и Западом - наиболее важный элемент интеллектуальной истории современной России [Koyre 1994, p. 10]. После XVIII в. Европа играла роль «конституирующего другого» в отношениях, посредством которых российская идентичность определялась и переопределялась [Malinova 2008, p. 41]. Запад был центром внимания как сторонников вестернизации, так и самобытности в том, как они толковали российскую идентичность [İsmayilov 2011 , p. 22]. Аналогичным образом европейские идеи оказали глубокое влияние на развитие политической мысли и дискуссии об идентичности в Турции. Турецкий историк профессор Зафер Топрак указал на то, что процесс построения нации в Турции был результатом отношений и диалога с Западом [Toprak 2002, p. 801].

И турки, и русские несколько раз пытались стать полноправными членами «клуба» великих европейских держав, партнерами западной политической системы и цивилизации на протяжении более чем 200 лет. Однако, как указали многие исследователи, они не были в полной мере приняты Западом как часть западной цивилизации [Тoynbee 2002; Ortayl1 2008; Rumelili, Morozov 2012]. Многие политические деятели Европы, такие как главный министр Франции в XVII в. Сюлли считали, что турок и русских надо держать подальше от Европы [Acar 2008, p. 65]. Более того, и турки, и русские использовались как «другие» при создании европейской идентичности. Европейцы видели в них азиатов и варваров, угрожающих европейской 
цивилизации [Neumann 1999]. По мнению известного турецкого историка, профессора Ильбера Ортайлы, с эпохи Возрождения Европа хотя старалась «держать Россию и Турцию подальше», но не оставила их вполне. Они стали первыми странами, которые столкнулись с вестернизацией как вызовом [Ortaylı 2008, p. 9-10]. С точки зрения другого турецкого историка, Мехмеда Али Кылычбая, Османская империя и Россия были ближайшими к Западу незападными странами [Kılıçbay 1985, p. 148]. Турецкий историк профессор Абдулла Гюндогду имеет несколько иное, примечательное понимание позиции России и Турции. В то время когда Россия была «европейцем» на Востоке, османы были жителями Востока, но оставались в поле зрения Запада [Gündoğdu 2019]. Таким образом, ни Россия, ни Турция никогда не представлялись участниками процесса Западноевропейской цивилизации.

Многие турецкие исследователи рассматривают Россию как зеркало, позволяющее лучше увидеть собственную страну. Чтобы проиллюстрировать данный подход, приведем рассуждения турецкого историка Гюндогду: «Мы можем провести аналогию между Россией и большим зеркалом. Она похожа на зеркало в полный рост возле двери, в которое вы смотрите на себя, прежде чем выйти из дома. Турции следует рассматривать Россию как зеркало для себя, как значимый критерий в контексте международных отношений и оценивать свою позицию с точки зрения России. Исторический процесс России и Турции имеет сходство и взаимодействие. Русская революция 1905 года и турецкая революция 1908 года объединяются с этой точки зрения и можно утверждать, что первая оказала влияние на последнюю» [Gündoğdu 2014, p. 1144-1145].

Турецкие ученые обычно датируют вестернизацию и модернизацию в России периодом от Петра Великого (1682) до 1905 г. [Yüksel 2006]. Примерно так же датируется и вестернизация Османской империи. С созданием СССР в 1922 г. и современной Турции в 1923 г. модернизация ускорилась: в России под лозунгами социалистической идеологии, а в Турции под знаменем кемалистской революции и реформы, нацеленных на вестернизацию. Однако в данной статье мы ограничимся анализом литературы, посвященной вестернизации / модернизации Османской и Российской империй. Во-первых, в последующий период различия между Россией и Турцией были слишком велики и носили идеологический характер; таким образом, анализ данного периода потребовал бы обсуждения и сравнения советской и кемалистской идеологии. Во-вторых, в отличие от прошлых этапов, когда две империи конкурировали друг с другом, в 1920-х годах Турция и СССР установили дружественные отношения. Таким образом, советская и кемалистская фазы турецкой и российской модернизации требуют отдельного исследования. 
В настоящей статье мы предлагаем анализ работ наиболее выдающихся турецких историков и социологов, изданных с 60 -х годов XX в. по настоящее время. Турецкие исследователи считают российскую вестернизацию более успешной по сравнению с османской и наряду с чертами сходства обнаруживают существенные различия между ними. Вместе с тем, на наш взгляд, в турецкой литературе недостаточно исследован вопрос о влиянии религии на вестернизацию обеих империй, о степени этого влияния в обеих странах.

\section{Значение термина "вестернизация" дяя турецких ученых}

Чтобы понять турецкий взгляд на вестернизацию Турции и России, прежде всего необходимо разобраться с тем, как понимается данное явление. В XVIII в. османы осознали свое отставание от промышленно развитой и модернизированной Европы. После XVIII в. для многих османских государственных деятелей и мыслителей вестернизация стала синонимом модернизации и цивилизации. Многие из них рассматривали вестернизацию как единственный путь модернизации. У них сложилось впечатление, что есть два варианта - «вестернизация или гибель» [Kalın 2019, p. 380]. Даже сегодня термины «вестернизация», «модернизация» и «цивилизация» иногда используются многими турецкими мыслителями как синонимы. По мнению Тарика Зафера Тунае, автора выдающейся работы о движениях в поддержку вестернизации в Турции, суть вестернизации заключается в попытке создания современного общества и либерального государства [Tunaya 2016, p. 17]. Либеральный мыслитель Мурат Белге, проводивший сравнительный анализ вестернизации в России и Турции, полагает, что модернизация связана с прогрессом и развитием, а не географией. Вестернизация, модернизация и становление капиталистических отношений переплетаются друг с другом с того момента, как они возникли на Западе [Belge 2016]. Некоторые турецкие ученые, такие как, например, Ниязи Беркес и Кылычбай, рассматривают секуляризм как принципиальный компонент вестернизации [Kilıçbay 1985, p. 147151; Berkes 1998]. По мнению Кылычбая, вестернизация - это перестройка незападного общества в соответствии с западными нормами. Он подчеркивает, что опыт Османской империи может служить хорошим примером для других нехристианских стран, поскольку демонстрирует, что вестернизация невозможна без секуляризации [Kılıçbay 1985, p. 147-151].

В то же время некоторые турецкие консерваторы и мыслители исламского толка отождествляют вестернизацию не только с модернизацией, но и с христианством. Они оппонируют вестернизации и модернизации европейского образца. Например, в отличие от Тунаи и Белге, известный турецкий консервативный мыслитель Джемиль Мерич резко критикует вестернизацию, западные парадигмы и готовность турецких интеллектуалов принять западную 
точку зрения. Мерич обвиняет турецких ученых в непонимании истинного значения Запада. Он подчеркивает, что, несмотря на свой материализм, Европа является преимущественно христианской. Следовательно, турки никогда не могут стать частью западной цивилизации. Более того, он ссылается на идею Данилевского о том, что невозможно перейти от одной цивилизации к другой [Meriç 1974]. Подобно Джемилю Меричу, многие турецкие консерваторы и религиозные мыслители выступают против вестернизации и западной цивилизации, начиная со времен Османской империи и до наших дней. Они считают, что Запад и вестернизация сродни христианской цивилизации. Напротив, профессор Ильбер Ортайлы отмечает, что рассмотрение Европы как «христианского клуба» не дает объяснения, почему Россия была исключена Европой из него, несмотря на то, что она христианская страна [Ortaylı 2008, p. 10]. Очевидно, что начиная с XIX в. многие турецкие мыслители интерпретировали вестернизацию с точки зрения цивилизации и модернизации.

Турецкие мыслители по-разному определяют реформы в Османской империи конца XVII - начала XX в. - одни называют их вестернизацией (batılilaşma) [Karpat 2002; Mardin 2005], другие - модернизацией (çağdaşlaşma, muasırlaşma, modernleşme) [Belge 2004; Kılıçbay 1985; Ortaylı 2005]. Однако все исследователи указывают на то, что османы воспринимали Запад как образец для модернизации. Именно поэтому в этой статье я выбираю термин «вестернизация». Этот термин также частично совпадает с примером России, потому что русские также воспринимали Запад как образец развития. Реформы в России начиная с Петра Великого и до 1905 г. определяются турецкими учеными как вестернизация, модернизация и европеизация. Однако они не используют термин «европеизация» для определения османской модернизации. По словам турецкого историка Кезбана Аджара, европеизация относится к попыткам России стать частью Европы. Европеизация - это различие между русскими и османскими моделями [Acar 2008, p. 62]. Причину этого различия также подчеркивает Мурат Белге, который заявил, что в то время, как османы пытались сохранить свою власть над Европой, прибегая к вестернизации, Россия стремилась стать частью Европы [Belge 2004]. Следовательно, термин «европеизация» не соответствует вестернизации Османской империи. Тем не менее оба термина часто переплетаются, когда речь заходит о процессах модернизации как Турции, так и России.

\section{Вестернизация в Османской и Российской империях}

Битва при Вене в 1683 г. стала поворотным моментом как для Европы, так и для османов. До битвы при Вене Османская империя занимала главенствующие позиции в Центральной и Юго-Восточной Европе. После поражения османов в сражении 1683 г. началось их отступление из Центральной 
Европы. Османы не только утратили влияние в Европе, но и начался общий упадок Империи. Однако до XVIII в. Османская знать не замечала, что их государство отстало от промышленно развитой и модернизированной Европы. До этого времени политические элиты и мыслители Османской империи представляли Запад лишь оплотом христианства. Они не только не знали о промышленных и политических революциях, происходивших в Европе, но и были убеждены в своем превосходстве.

В XVII-XIX вв. западные державы, включая Великобританию, Францию и Россию, одержали несколько побед над османами и захватили некоторые территории Османской империи, что заставило османов пересмотреть отношение к Западу. В XIX в. они начали воспринимать Запад как воплощение модернизации, цивилизации и прогресса. Пришлось признать, что вестернизация - единственный способ обеспечить выживание империи [Tunaya 2016, p. 18]. Турецкий профессор истории Гюндогду также говорит о том, что завоевание Россией османского Крыма в конце XVIII в. доказало неизбежность вестернизации. Потеря Крыма продемонстрировала туркам-османам не только силу России, но и то, что она стала серьезным конкурентом Османской империи на пути вестернизации. Потеря Крыма привела османов к осознанию принципов вестернизации, изложенным Петром Великим, которого турки ранее называли «Дэли Петро» (Безумный Петр) [Gündoğdu 2017, p. 14-15]. Таким образом, спустя 100 лет после петровской вестернизации России, в конце XVIII в., при султане Селиме III началась вестернизация Османской империи. После Селима III правил султан Махмуд II (также представлявшийся некоторыми как турецкий Петр Великий), пытавшийся в начале XIX в. спасти империю, находившуюся в упадке. И Петр Великий, и Махмуд II начинали свои реформы с армии. Подобно тому, как Петр Великий распустил стрелецкое войско, сопротивлявшееся его реформам, Махмуд II упразднил корпус янычар (Yeniçeri Ocağı), который представлял главное препятствие для его реформ. Как указывают многие турецкие исследователи, эти события свидетельствуют о значительном сходстве между турецкой и русской вестернизациями [Belge 2004; Ortayli 2008]. Следует отметить, что эти события также уменьшили влияние религии (православной церкви в России и улемов в Османской империи) [Acar 2008, p. 69-70]. Более того, и Петр Великий, и Махмуд II осуществили социальную модернизацию и ввели правила для военных и государственных чиновников, такие как бритье бород и принятие европейской моды. Из-за западных преобразований некоторые консерваторы и противники реформ в Османской империи называли султана Махмуда II «Явур Падишах» (неверный султан). Впрочем необходимо отметить и различия между вестернизациями Петра Великого и Махмуда II. Историк Кезбан Аджар видел таковые в отношениях между аристократией и государством. Влияние османских аянов (местных нотаблей) полностью исчезло с вестерни- 
зацией Махмуда II в попытках усилить контроль над государством и бюрократией. Это препятствовало появлению османской аристократии, которая, как предполагается, сыграла бы роль пионеров модернизации [Acar 2008, p. 73-77]. Белге указывает на другое различие между двумя вестернизациями. Петр Великий добился большего прогресса в вестернизации по сравнению с Махмудом II, поскольку обладал более широкими полномочиями для осуществления реформ. Белге определяет петровскую модернизацию как авторитарную [Belge 2016, p. 27-28]. Таким образом, можно утверждать, что между вестернизацией в обеих странах есть как сходство, так и различия. Более того, по мнению многих турецких ученых, Петр Великий добился большего успеха чем султан Махмуд II с точки зрения вестернизации, затронувшей не только время правления обоих правителей, но и последующие периоды. Они связывают этот успех с тем, что Россия не только действовала более решительно, но и провела более радикальные и всеобъемлющие реформы раньше и быстрее, чем Османская империя [Berkes 2019; Belge 2004; Gündoğdu 2019; Kilıçbay 1985; Acar 2008; Karpat 2002]. Кроме того, процесс вестернизации Османской империи чаще прерывался из-за реакционных восстаний, таких как Восстание Патрона Халила и дворцовые перевороты 1807-1808 гг. [Ülken 2013, p. 13-15; Belge 2016, p. 25].

В Османской империи за процессами вестернизации и модернизации последовали Указ Танзимата от 1839 г. и Первая конституционная эра в 1876 г., ознаменовавшаяся движением за конституционные реформы. В результате Османская империя ввела конституционную монархию раньше, чем Россия, хотя процесс вестернизации там начался столетием позже [Ortayl1 2007, p. 28].

Ни в одной из рассматриваемых стран вестернизация не осуществлялась снизу вверх [Tunaya 2016]. Ни в турецком, ни в российском обществах не было явного стремления или требования вестернизации.

По мнению турецких исследователей, одним из наиболее важных отличий российской вестернизации, обусловивших ее успешность, были экономические факторы [Belge 2016; Berkes 2019; Gündoğdu 2017; Acar 2008; Yüksel 2006]. Османская интеллигенция и политические элиты рассматривали вестернизацию в большей степени с точки зрения военной модернизации и конституционного движения, игнорируя при этом необходимость индустриализации. Поэтому они упустили из виду экономические корни модернизации Европы. В силу этого несмотря на вестернизацию и либерализацию Османская империя сохранила экономические структуры традиционного общества, что привело к проникновению в ее экономику промышленно развитых западных держав и способствовало установлению зависимости от иностранного капитала. По словам Мурата Белге, бюрократия играла более значимую роль в Османской империи и России по сравнению с европейскими странами, в 
которых существовали либеральные режимы, поскольку в обеих странах была абсолютная монархия и слабый частный капитал. Однако он отмечает, что в то время, как русские держали свой собственный капитал в России, турки в Османской империи вообще не имели капитала. Османская буржуазия состояла из немусульманских (не тюркских) меньшинств, которые извлекали выгоду из вестернизации и либерализации Османской империи. Несмотря на то, что турки казались истинными владельцами империи, экономика Османской империи находилась под контролем немусульманских меньшинств [Belge 2016, p. 340-341]. Поддерживая точку зрения Белге, Гюндогду также отмечает, что в то время как Османская империя поддерживала асимметричные / несбалансированные экономические отношения с западным капиталом (что в результате оказывалось в пользу Запада), у России отношения с западным капиталом были гораздо более сбалансированные [Gündoğdu 2017, p. 14]. Аджар обращает внимание на такое явление, как капитуляции - контракты между Османской империей и европейскими державами, предоставлявшие европейским торговцам право въезда в Турцию с освобождением от местного суда, налогообложения и набора в армию. Эти капитуляции сделали Османскую империю рынком сырьевых ресурсов для Европы и зависимой от европейских капиталов. Что касается России, то подобного не происходило [Acar 2008, p. 78]. Все эти экономические факторы являются важными различиями между русской и османской вестернизацией. Османская империя с экономической точки зрения больше пострадала от вестернизации из-за неспособности к индустриализации и отсутствия национальной буржуазии.

Рост экономической зависимости от Европы наряду с вестернизацией породили негативную реакцию и движение против реформ в Османской империи. Это сопротивление вестернизации и модернизации определяется некоторыми турецкими исследователями как «гериджи» (реакционное) [Berkes 2019; Ülken 2013, p. 13-15]. Концепции турецких ученых Ниязи Беркеса и Тарыка Зафера Туная очень ценны для понимания борьбы между «прогрессивными» (модернистско-светскими силами) и «реакционными» (религиозными, антимодернистскими силами), которая наблюдается со времен Османской империи вплоть до настоящего времени [Berkes 2019; Tunaya 1991]. Поскольку вестернизация Османской империи началась спустя столетие после начала российской вестернизации, критика этого процесса возникла в Османской империи позже, чем в России. Подобно русским славянофилам и панславистам, исламисты и другие «реакционеры» в Османской империи критиковали вестернизацию. Профессор Мурат Белге утверждает, что по сравнению с Россией в Османской империи было больше сопротивления реформам из-за того, что Османская держава имела более устойчивое общество, многовековую государственную структуру и плюрализм в разделении власти, что создавало трудности для преобразований [Belge 2016, p. 24-26]. 
Можно выделить три типа реакции османско-турецких интеллектуалов и представителей политических элит на вестернизацию. Первый - связан с признанием того, что реформы необходимы и неизбежны. Второй - заключается в категорическом отказе от вестернизации. Третий тип реакции - поддержка ограниченных преобразований. Вполне естественно, что главными критиками реформ были представители реакционных взглядов [Berkes 2019, p. 182-199]. Турецкий социолог Ниязи Беркес утверждает: «Религиозный железный занавес между христианством и исламом стал постоянным барьером и усугубил обычные трудности с внесением изменений в традиционный порядок. Эта религиозная реакция не только стала характерной чертой турецкой трансформации, но и распространилась на все мусульманские общества во второй половине XIX в. в идеологии панисламизма. Эта особенность отличала турецкую трансформацию от японской или даже русской, в которых вестернизация не встречала противодействия по религиозным мотивам» [Berkes 1998, p. 52].

В отличие от Беркеса, профессор Белге полагает, что, будучи христианской страной, Россия легче адаптировалась к Западу, чем мусульмане-османы. Между религиозными направлениями был конфликт, а не гармония. Белге утверждает, что главным препятствием для вестернизации Османской империи было ее славное прошлое, поскольку османы полагали, что они создали великую империю благодаря превосходству своей религии. Они считали перемены предательством по отношению к своему прошлому. Русские же, в отличие от османов, были более подвержены реформаторским настроениям, поскольку у них была более молодая империя [Belge 2016, p. 24-26]. Кроме того многие турецкие и западные исследователи, такие как Тойнби, подчеркивали, что ислам вызвал сильное сопротивление вестернизации в Османской империи [Toynbee 2002]. Соглашаясь с Беркесом в том, что исламское и религиозное сопротивление было значительным препятствием на пути вестернизации Османской империи, отметим, что влияние религии на османскую и русскую вестернизации все же требует более тщательного исследования.

Еще одним существенным отличием были цели реформ. Турецкие ученые сходятся во мнении, что главной целью османской вестернизации было сохранение существующего положения вещей [Karpat 2002; Belge 2004; Acar 2008]. В то время как Россия вестернизировалась, чтобы стать сильной империей и частью европейской системы, османы стремились к вестернизации, чтобы спасти свою разрушающуюся империю и вернуться к великолепным временам [Belge 2004, p. 43-56]. Аджар также отмечает, что целью Петра Великого в проведении российской модернизации было участие в делах Европы. Цель же Османской империи в преобразованиях состояла в том, чтобы сохранить свое влияние над Европой. В то время как российская модернизация имела «наступательную» характеристику, османская модернизация была «оборонительной» [Acar 2008, p. 65]. Этот подход позволяет нам оценивать 
османскую вестернизацию как оборонительную модернизацию, а российскую вестернизацию - как наступательную. Если для османов вестернизация была «инструментом», для русских она выступала скорее «целью». Для османов вопрос заключался в том, как модернизироваться с минимальной вестернизацией, тогда как для России вопрос состоял в том, чтобы вестернизироваться как можно больше.

Чтобы понять, как русские оказались более успешными, чем османы в деле модернизации, турецкие ученые прибегают к сравнению статистических данных, например уровня грамотности. Уровень грамотности в России достиг 40\% в начале XX в., а в Османской империи в 1801-1900 гг. он вырос только с 1\% до 5-10\% [Acar 2008, p. 79]. В то время как в России со времен Петра Великого до большевистской революции было издано больше 200 тыс. книг, даже в период Танзимата Османской империи было напечатано всего лишь несколько тысяч книг [Ortayl1 2007, p. 18-19]. Белге также отмечает, что Россия победила в большинстве войн между Россией и Османской империей. Результаты этих войн свидетельствуют о том, что Россия оказалась более успешной, чем Османская с точки зрения проведения реформ [Belge 2016, p. 23].

\section{Заключение}

По мнению турецких ученых, в вестернизации Россия была более успешной и провела более радикальные и всеобъемлющие реформы раньше и быстрее, чем Османская империя. В вестернизации двух стран были как сходства, так и различия. И османы, и русские считали Европу образцом для модернизации. В обеих странах вестернизация и модернизация были осуществлены посредством реформ, идущих сверху вниз. Существовали также сходные моменты в реформах русского царя Петра Великого и османского султана Махмуда II, такие, например, как упразднение корпуса стрельцов и янычар, препятствовавших реформам. Однако хотя османы начали вестернизацию на столетие позже, чем Петр Великий свои преобразования. Примечательно, конституционная монархия в Османской империи возникла раньше, чем в России. Кроме того, в двух странах были различия в целях вестернизации. В то время как османы стремились возродить империю и вернуть ей былую славу, Россия стремилась стать сильной европейской страной. В этом контексте вестернизация была целью для русских и инструментом для османов. В отличие от России, вестернизация и либерализация Османской империи привели к проникновению в нее промышленно развитых западных держав. Это также вызвало политические движения, которые выступали против реформ. По сравнению с Россией в Османской империи была большая нестабильность и большее сопротивление вестернизации. Некоторые турецкие 
ученые, такие как Ниязи Беркес [Berkes 1998], утверждают, что из-за различия в религии в мусульманской Турции имелось больше препятствий для вестернизации, чем в православной России.

Однако влияние ислама и православия на османскую и русскую вестернизации не подвергалось глубокому сравнению и тщательному анализу. В этом отношении в турецкой литературе нет достаточного материала для сравнения роли религий в османской и русской вестернизации. Интересно, что хотя Российская империя добилась большего прогресса с точки зрения вестернизации, профессор Бельге указывает на то, что даже сегодня - не говоря уже о XIX в. - невозможно утверждать, что Россия и Турция смогли достичь стандартов современного западного общества [Belge 2016].

Автор выражает благодарность Малиновой Ольге Юрьевне за помощь в редактуре статьи.

\section{Библиография}

Acar K. Osmanlı ve Rus Modernleşmesine Dair Bazı Görüşler // Muhazafakar Düşünce. 2008. Cilt 4. N 16-17. S. 59-86.

Agoston G. Military Transformation in the Ottoman Empire and Russia, 1500-1800 // Kritika: Explorations in Russian and Eurasian History. 2011. Vol. 12. N 2. P. 281-319.

Alatlı A. Aydınlanma Değil, Merhamet: Gogol'un İzinde. İstanbul: Everest Publications. 2005. $501 \mathrm{~s}$.

Belge M. Step ve Bozkır: Rusça ve Türkçe Edebiyatta Doğu-Batı Sorunu ve Kültür. İstanbul: İletişim Publishing, 2016. $356 \mathrm{~s}$.

Belge M. Batılılaşma: Türkiye ve Rusya // Modern Türkiye'de Siyasi Düşünce. İstanbul: İletişim Publishing. 2004. 3. Cilt: Modernleşme ve Batıcılık. S. 43-56.

Berkes N. The Development of Secularism in Turkey. London: C. hurst and Co. Publishers. $1998.537 \mathrm{p}$.

Berkes N. Türk Düşününde Batı Sorunu. 4. Baskı. İstanbul: Yapı Kredi Publications, 2019. $276 \mathrm{~s}$.

Brisku A. Political Reform in the Ottoman and Russian Empires: A Comparative Approach. Bloomsbury. 2017. 257 p.

Esenbel S. Japon Modernleşmesi ve Osmanlı. 3. Baskı. İstanbul: İletişim Publishing. 2019. $448 \mathrm{~s}$.

Gündoğdu A. Türkiye ve Rusya, Kaçınılmaz Etkileşmeler Kaçınılmaz Benzeşmeler // 2023 Dergisi. 2006. N 62. S. 44-46.

Gündoğdu A. Türk Dünyasında Milli Egemenlik Fikrinin Gelişimi // Belgi. 2014. Cilt 8. N 2. S. 1139-1149.

Gündoğu A. Türkiye'de İslamc1lı ve Gelenek // Historia 1923. 2017. Cilt 3. N 1. P. 8-22.

Gündoğdu A. İsmail Gaspıralı ve Yenilikçi Çizgisi // Yüksek Öğretim Dergisi. 2019. Cilt 14. Sorun 4. S. 40-47.

İsmayilov M. Avrasyacılık: Mukayeseli Bir Okuma Türkiye ve Rusya Örneği. Ankara: Doğu Batı Publications. 2011. $405 \mathrm{~s}$

Kalın İ. Ben, Öteki ve Ötesi. 21. Baskı. İstanbul: İnsan Publications. 2019. 568 s. 


\section{РОССИЯ ВЧЕРА, СЕГОДНЯ, ЗАВТРА}

Karpat K. Osmanlı Modernleşmesi / Çeviri A.Z. Durukan, K. Durukan. Ankara: İmge Publisher. 2002. $163 \mathrm{~s}$. $611 \mathrm{~s}$.

Karpat K. Osmanlı'da Değişim, Modernleşme ve Uluslaşma. Ankara: İmge Publisher. 2006.

Kılıçbay M.A. Osmanlı Batılaşması // Tanzimat'tan Cumhuriyet'e Türkiye Ansiklopedisi. İstanbul: İletişim Publications. 1985. Cilt 1. S. 147-152.

Koyre A. 19. Yüzyıl Başlarında Rusya'da Batıcılık, Ulusçuluk ve Felsefe. İstanbul: Belge Publications. 1994. $140 \mathrm{~s}$.

Malinova O. Creating meanings and traps: competing interpretations of the idea of nation in the debates of Russian Slavophiles and Westernisers in the 1840 s. // European Review of History: Revue Europeenne d'Histoire. 2008. Vol. 15. N 1. P. 41-54.

Mardin Ş. Türkiye'de Toplum ve Siyaset - Makaleler 1. İstanbul: İletişim Publications. 2005. $312 \mathrm{~s}$.

Meriç Ç. Umrandan Uygarlığa. İstanbul: İletişim Publications. 1974. 371 s.

Neumann I. Uses of the Other: «The East» in European Identity Formation. Minneapolis: The University of Minnesota Press. 1999. 281 p.

Ortaylı İ. İmparatorluğun En Uzun Yüzyılı. İstanbul: Akım Publications. 2005. 296 s.

Ortaylı İ. Batılılaşma Yolunda. İstanbul: Merkez Kitaplar Publisher. 2007. 248 s.

Ortaylı İ. Avrupa ve Biz. İstanbul: Türkiye İş Bankası Kültür Publications. 2008. 314 s.

Rumelili B., Morozov V. The External Constitution of European Identity: Russia and Turkey as Europe-makers. Cooperation and Conflict. 2012. Vol. 47. N 1. P. 28-48.

Toprak Z. Türkiye'de «Narodnik» Milliyetçiliği ve Halkçıllk (1908-1918) // Türkler. Ankara:

New Turkey Strategic Research Center Yeni Türkiye Publications. 2002. Cilt 14. S. 801-806.

Toynbee A.J. Türkiye ve Avrupa. 2. Baskı. İstanbul: Örgün Publisher. 2002. 253 s.

Tunaya T.Z. İslamcılık Akımı [Islamism Movement]. İstanbul: Simavi Publications. 1991. $296 \mathrm{~s}$.

Tunaya T.Z. Türkiye'nin Siyasi Hayatında Batılılaşma Hareketleri. 3. Baskı. İstanbul: İstanbul Bilgi Üniversitesi Publications. 2016. 236 s.

Ülken H.Z. Türkiye'de Çağdaş Düşünce Tarihi. 15. Baskı. İstanbul: Türkiye İş Bankası Kültür Publications. 2013. $776 \mathrm{~s}$.

Yüksel D.Y. Rus Modernleşmesi ve Türkiye (1682-1905): Doktora tezi / Hacettepe University. Ankara, 2006. $353 \mathrm{~s}$.

\section{References}

Acar K. Osmanlı ve Rus Modernleşmesine Dair Bazı Görüşler [Opinions on Ottoman and Russian Modernizations]. Muhazafakar Düşünce. 2008. Vol. 4 N 16-17. P. 59-86.

Agoston G. Military Transformation in the Ottoman Empire and Russia, 1500-1800. Kritika: Explorations in Russian and Eurasian History. 2011. Vol. 12. N 2. P. 281-319.

Alatlı A. Aydınlanma Değil, Merhamet: Gogol'un İzinde [Not Enlightenment, Compassion: In the Footsteps of Golog]. İstanbul: Everest Publications. 2005. 501 p.

Belge M. Step ve Bozkır: Rusça ve Türkçe Edebiyatta Doğu-Batı Sorunu ve Kültür [Step and Bozkır: The East-West Issue and Culture in Russian and Turkish Literatures]. İstanbul: İletişim Publishing, 2016. $356 \mathrm{p}$.

Belge M. Batılılaşma: Türkiye ve Rusya [Westernization: Turkey and Russia]. Modern Türkiye'de Siyasi Düşünce]. İstanbul: İletişim Publishing. 2004. 3. Cilt: Modernleşme ve Batıcılık [Political Thought in Modern Turkey 3. Volume: Modernization and Westernism]. P. 43-56.

Berkes N. The Development of Secularism in Turkey. London: C. hurst and Co. Publishers. 1998. $537 \mathrm{p}$. 
Berkes N. Türk Düşününde Bat1 Sorunu [The West Issue in Turkish Thought]. $4^{\text {th }}$ edn. İstanbul: Yap1 Kredi Publications, 2019. 276 p.

Brisku A. Political Reform in the Ottoman and Russian Empires: A Comparative Approach. Bloomsbury. 2017. 257 p.

Esenbel S. Japon Modernleşmesi ve Osmanlı [Japanese Modernization and the Ottoman]. $3^{\text {th }}$ edn. İstanbul: İletişim Publishing. 2019. 448 p.

Gündoğdu A. Türkiye ve Rusya, Kaçınılmaz Etkileşmeler Kaçınılmaz Benzeşmeler [Turkey and Russia: Inevitable Interactions, Inevitable Similarities]. 2023 Dergisi [2023 Journal]. 2006. N 62. P. 44-46.

Gündoğdu A. Türk Dünyasında Milli Egemenlik Fikrinin Gelişimi [The Development of National Sovereignty Idea in the Turkic World]. Belgi. 2014. Vol. 8. N 2. P. 1139-1149.

Gündoğu A. Türkiye'de İslamcıllk ve Gelenek [Islamism and Tradition in Turkey]. Historia 1923. 2017. Vol. 3. N 1. P. 8-22.

Gündoğdu A. İsmail Gaspıralı ve Yenilikçi Çizgisi [İsmail Gaspıralı and His Reformist Perspective]. Yüksek Öğretim Dergisi [Journal of Higher Education]. 2019. Vol. 14. Issue 4. P. 40-47.

İsmayilov M. Avrasyacılık: Mukayeseli Bir Okuma Türkiye ve Rusya Örneği [Eurasianism: Comparative Reading of Turkey and Russia Cases]. Ankara: Doğu Batı Publications. 2011. 405 p.

Kalın İ. Ben, Öteki ve Ötesi [Me, Other and Beyond]. $21^{\text {sth }}$ edn. İstanbul: İnsan Publications. 2019. $568 \mathrm{p}$

Karpat K. Osmanlı Modernleşmesi [Ottoman Modernization]. Translated by A.Z. Durukan, K. Durukan. Ankara: İmge Publisher. 2002. 163 p.

Karpat K. Osmanlı'da Değişim, Modernleşme ve Uluslaşma [Changing, Modernization and Nation Building in the Ottoman]. Ankara: İmge Publisher. 2006. 611 p.

Kılıçbay M.A. Osmanlı Batılaşması [Ottoman Westernization] in Tanzimat'tan Cumhuriyet'e Türkiye Ansiklopedisi [Encyclopedia of Turkey from the Tanzimat to Turkey] İstanbul: İletişim Publications. 1985. Vol. 1. P. 147-152.

Koyre A. 19. Yüzyıl Başlarında Rusya'da Batıcılık, Ulusçuluk ve Felsefe [Westernism, Nationalism and Philosophy in Russia in the early $19^{\text {th }}$ century]. İstanbul: Belge Publications. 1994. $140 \mathrm{p}$.

Malinova O. Creating meanings and traps: competing interpretations of the idea of nation in the debates of Russian Slavophiles and Westernisers in the 1840 s. European Review of History: Revue Europeenne d'Histoire. 2008. Vol. 15. N 1. P. 41-54.

Mardin Ş. Türkiye'de Toplum ve Siyaset - Makaleler 1 [Society and Politics in Turkey - Articles 1]. İstanbul: İletişim Publications. 2005. 312 p.

Meriç Ç. Umrandan Uygarlığa [From Islamic Civilization to Spurious Civilization]. İstanbul: İletişim Publications. 1974. $371 \mathrm{p}$.

Neumann I. Uses of the Other: «The East» in European Identity Formation. Minneapolis: The University of Minnesota Press. 1999. 281 p.

Ortaylı İ. İmparatorluğun En Uzun Yüzyılı [The Longest Century of the Empire]. İstanbul: Akım Publications. 2005. 296 p.

Ortaylı İ. Batılılaşma Yolunda [On the Way for Westernization]. İstanbul: Merkez Kitaplar Publisher. 2007. 248 p.

Ortaylı İ. Avrupa ve Biz [Europe and Us]. İstanbul: Türkiye İş Bankası Kültür Publications. 2008.314 p.

Rumelili B., Morozov V. The External Constitution of European Identity: Russia and Turkey as Europe-makers. Cooperation and Conflict. 2012. Vol. 47. N 1. P. 28-48.

Toprak Z. Türkiye'de «Narodnik» Milliyetçiliği ve Halkçılık (1908-1918) [«Narodnik» Nationalism and Populism in Turkey (1908-1918)]. Türkler [The Turks]. Ankara: New Turkey Strategic Research Center Yeni Türkiye Publications. 2002. Vol. 14. P. 801-806. 


\section{РОССИЯ ВЧЕРА, СЕГОДНЯ, ЗАВТРА}

Toynbee A.J. Türkiye ve Avrupa [Turkey and Europe]. $2^{\text {nd }}$ edn. İstanbul: Örgün Publisher. 2002. $253 \mathrm{p}$.

Tunaya T.Z. İslamcılık Akımı [Islamism Movement]. İstanbul: Simavi Publications. 1991 296 p.

Tunaya T.Z. Türkiye'nin Siyasi Hayatında Batılılaşma Hareketleri [Westernization Movements in Turkish Political Life]. $3^{\text {rd }}$ edn. İstanbul: İstanbul Bilgi Üniversitesi Publications. 2016. 236 p.

Ülken H.Z. Türkiye'de Çağdaş Düşünce Tarihi [Contemporary Thought History in Turkey]. 15 th edn. İstanbul: Türkiye İş Bankası Kültür Publications. 2013. 776 p.

Yüksel D.Y. Rus Modernleşmesi ve Türkiye (1682-1905) [Russian Modernization and Turkey (1682-1905)]: PhD Thesis. Hacettepe University. Ankara, 2006. 353 p. 